\title{
Economic Advantages of Community Currencies
}

\author{
Sarah Zeller ${ }^{\mathbb{D}}$ \\ Faculty of Business and Economics, Technische Universität Dresden, 01062 Dresden, Germany; \\ sarah.zeller@tu-dresden.de
}

Received: 12 September 2020; Accepted: 30 October 2020; Published: 3 November 2020

\begin{abstract}
Community currencies are only sometimes economically advantageous. We focus on seasonal changes in money supply and assume that community currencies stabilize the money supply in a local community. This leads to additional transactions during seasons of insufficient supply of national currency. We hypothesize community currencies are therefore economically advantageous in a surrounding of seasonally insufficient money supply. We test the hypothesis qualitatively with two case studies, the German Chiemgauer and the Kenyan Sarafu Credit. We find community currencies are only economically advantageous in an environment of insufficient liquidity.
\end{abstract}

Keywords: community currencies; money supply; seasonal liquidity; complementary currencies

\section{Introduction}

Since their introduction, one of the aims of the grass-roots movement of community currencies has been to improve the economic situation of its surroundings by offering an alternative to traditional currencies. Recently implemented community currencies especially aim to improve the local economy in promoting sustainable development (Michel and Hudon 2015, p. 160). While some networks, like Kenyan Bangla-Pesa and Argentinian Red de Trueque show evidence of an economic impact, others, like the British Bristol Pound or US-American Ithaca Hours, lack evidence-based economic advantages even years after introduction (Ruddick et al. 2015; Gomez and Helmsing 2008; Marshall and O'Neill 2018; Krohn and Snyder 2008). How can this disparity be explained?

Economic advantages seem to appear as a community currency responds "to a failure within the existing monetary system" (Slay 2011, p. 13). In this paper, we focus on seasonal shocks in the money supply, specifically seasonally insufficient money supply. This leads to so-called "lean seasons" (De Janvry et al. 2002, p. 1621) during which some transactions are prevented by insufficient liquidity, decreasing a local economy's welfare. In this situation, a community currency addresses an actual need in providing a stable money supply, enabling transactions which usually do not take place during the lean season. Thus, it improves a community's economic situation. In our empirical section, we find that community currencies are indeed economically advantageous in a surrounding of seasonally insufficient liquidity.

Building on previous research of both community currencies and liquidity, the next section provides a theoretical framework and develops a working hypothesis of when community currencies are economically advantageous. Section 3 tests our hypothesis in two case studies, German Chiemgauer and Kenyan Sarafu Credit, discusses the findings and elaborates on limitations. The last section concludes.

\section{Theoretical Framework}

This section provides an overview on community currencies and the issue of seasonally insufficient money supply. It then draws attention to a gap which community currencies may fill and derives a working hypothesis. 


\subsection{Community Currencies}

Community currencies are a sub-group of so-called complementary currencies - which are so termed because they function complementarily to a major currency, providing an additional money supply (Seyfang and Longhurst 2013, p. 65). The sub-group of community currencies are distinguished by their aim to "support and build more equal, connected and sustainable societies" (CCIA 2015, p. 43) for a specifically defined group (Seyfang and Longhurst 2013, p. 65). One possibility to define such a group is using geographic boundaries, which we focus on. While community currencies may also address ecological or social aims, we solely focus on the economic impact which community currencies have.

Essentially the same as any other currency, a community currency is used as a means of payment. It may hold the traditional functions of money: means of exchange, store of value and unit of account (Collins et al. 2012, p. 39). The function of store of value is debated in literature (e.g., Zagata 2004, p. 481; Slay 2011, p. 3; Martignoni 2012, p. 5; CCIA 2015, p. 100), which we address in Section 2.2. Some community currencies require collateral, that is, national currency needs to be exchanged to obtain the community currency. Others work as a mutual credit system, using peer pressure as a form of social collateral and enabling access to anyone within the network. As such, it is created between members as a transferable loan without interest (Bonanno 2018, p. 91). Restricted to a geographical area, a community currency covers only a specific group which accepts the currency as an additional means of payment. As a community currency is usually not convertible into another currency (including the official national one), it cannot leave the region of validity and as such cannot become scarce. Thus, it may complement other currencies with constant additional liquidity (Schraven 2001, p. 9) or an additional form of money supply, providing an alternative when the supply of official currency is not sufficient.

The origins to this movement criticizing money lie in the 1920s. Motivated by Silvio Gesell's theory of freigeld, which translates freely into "free money", a movement criticizing money grew stronger in the 1920s. In their focus was the inherent property of money to keep its value stable while physical investments do not (Godschalk 2011, p. 4). The movement especially criticized the overly slow circulation of money and aimed to speed it up using a new kind of currency. It had the inherent feature to continually lose its value, which was termed demurrage. Most prominently, the Austrian town of Wörgl introduced a community currency in 1932, during an economic recession. Unemployment rates decreased due to an increase in commercial interactions within the community network; investments and employment were paid for with community currency and could, in consequence, be increased. Demurrage forced the money to circulate more quickly, which led to a social product nine times as efficient as conventional money. However, the central bank stopped the experiment six months after it had started (Lukschandl 2020).

The idea fell dormant after the initial experiments in the 1930s but found a revival in the 1990s. Since then, numerous community currencies have been introduced in the Global South and the Global North which vary greatly in their respective implementations. As of 2012, over 5000 complementary currencies had been established (Martignoni 2012), with 3418 complementary currencies still active in that year (Seyfang and Longhurst 2012, p. 11). Academic evaluation has increased in the past decades, allowing for a closer study of economic and social impacts. In academia, the impact of community currencies is debated, especially on an economic level.

Despite the fact that community currencies are sometimes economically motivated, not many studies show economic advantages. Only half of the community currencies have any economic impact, while only a third enables access to goods and services which would otherwise be unaffordable. Only a quarter of community currencies increase members' income (Michel and Hudon 2015, p. 165). In the Global South, Bangla-Pesa and Red de Trueque are prominent examples of community currencies with clear economic benefits. Within the Bangla-Pesa community, $83 \%$ of members reported an increase of sales, with transactions in the community currency accounting for $22 \%$ of average daily sales (Ruddick et al. 2015, pp. 27-28). The Red de Trueque in Argentina gained momentum during 
an economic crisis 1999-2002 (Gomez and Helmsing 2008, p. 2495). At its peak, up to $25 \%$ of participant households' income was earned in the community currency. It even provided something close to a minimum wage employment (Slay 2011, pp. 13-14). On the other hand, community currencies in the Global North such as the Bristol Pound and Ithaca Hours lack evidence of economic benefits. The Bristol Pound does not facilitate local procurement, nor does it add to local production (Marshall and O'Neill 2018, p. 277). A survey found that for two-thirds of Ithaca Hours members, the community currency does not enable access to goods or services they otherwise would not be able to access (Slay 2011, p. 13). Additionally, Krohn and Snyder (2008, p. 65) did not find quantitative evidence of community currency-related growth. How can the discrepancy between community currencies with and without economic benefits be explained?

One argument is that community currencies appear to provide economic advantages when addressing a failure within the existing monetary system (Slay 2011, p. 13). We follow this line of thought and introduce the issue of seasonal shortages in money supply as a failure within the existing system in the next section. We then elaborate on how community currencies may help address this issue.

\subsection{Seasonal Shortages in Money Supply}

In a modern society, the money supply in circulation serves three functions: unit of account, means of exchange, and store of value (Collins et al. 2012, p. 39). While the unit of account is an abstract measure to compare different goods and services, the latter two functions are economically more directly meaningful. As a means of exchange, money ensures individuals meet their demands of goods and services. Instead of offering goods or services in direct return, they use money as a fungible intermediary. As a store of value, money keeps a stable value over the course of time (Godschalk 2011, p. 4). These two functions of money are mutually exclusive; if money is exchanged for a good or service, it cannot be saved at the same time.

To profit from the means of exchange function of money, individuals and societies as a whole need to ensure a sufficient money supply to enable all possible transactions, or a sufficient level of liquidity. This can be understood within the framework of the equation of exchange,

$$
E=M \times V=P \times T
$$

where $M$ refers to the money supply, $V$ to the velocity with which the money circulates, $P$ to the prices of goods and services which are traded, and $T$ to the number of transactions taking place (Fisher 1912, p. 26). Both sides of the equation describe an economy's gross domestic product (GDP). We understand the right side of the equation as a given constant determined by the equilibrium of demand and supply. Although we acknowledge the impact of changes in the velocity V to be important (as emphasized by Stodder 2009; De la Rosa and Stodder 2015; Stodder and Lietaer 2016), we assume it to be constant to focus on the impact of money supply $\mathrm{M}$. If the money supply $\mathrm{M}$ is sufficient to fulfill all desired transactions $\mathrm{T}$ at prices $\mathrm{P}$, we speak of "sufficient liquidity". However, if the money supply $\mathrm{M}$ is insufficient to fulfill an individual's or a society's demands, we speak of "insufficient liquidity". In this state, money cannot completely function as a means of exchange, preventing possible transactions. Since consumers lack sufficient funds, supply does not fully meet demand. This leads to a decreased GDP, either for an entire nation or in a local economy. This imperfect allocation of goods and services leads to both excess supply on the producers' side and excess demand from the consumers' perspective, as can be seen in Figure 1. Insufficient liquidity thus induces a negative welfare effect. 


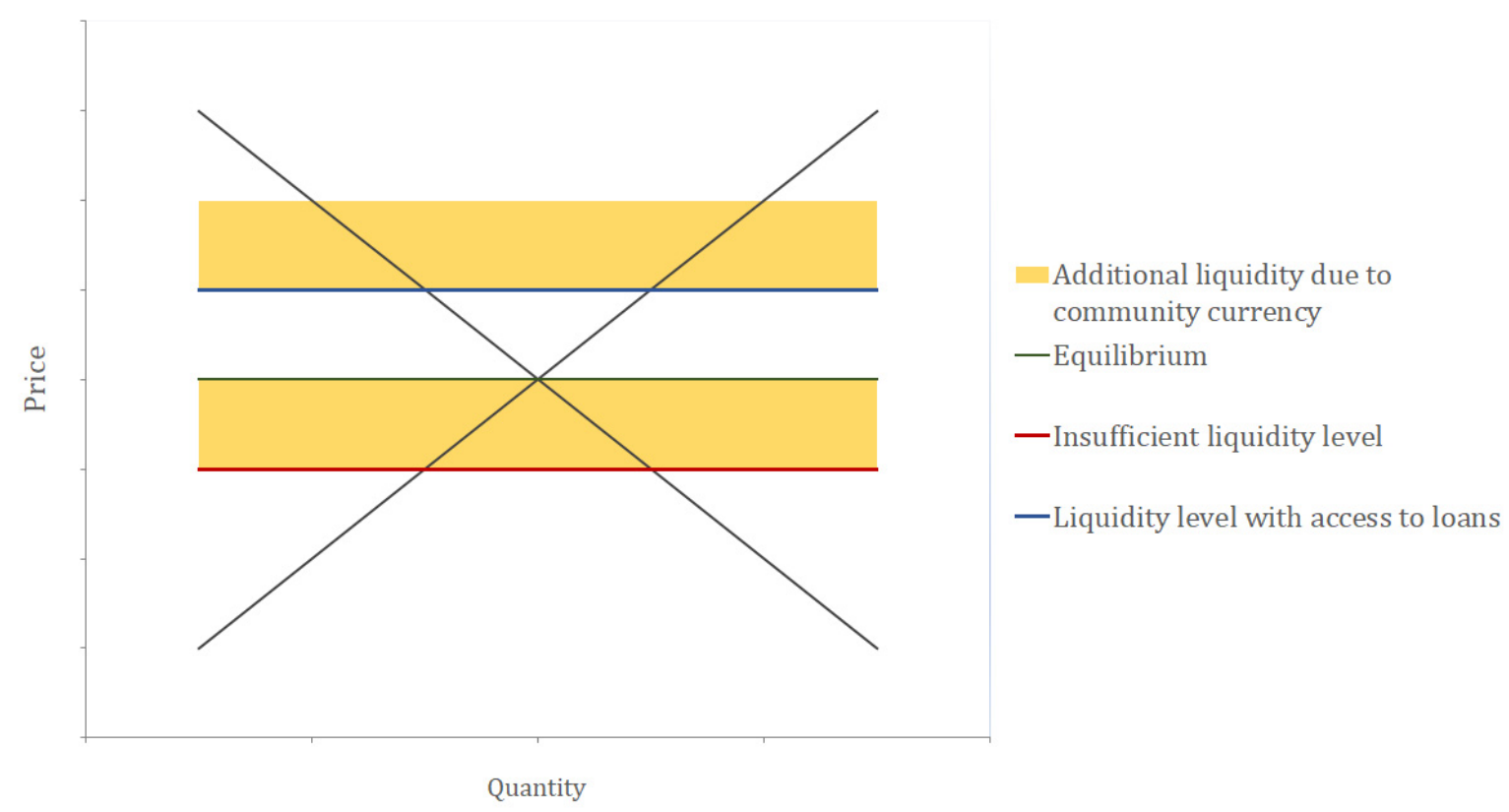

Figure 1. Additional liquidity due to a community currency.

While constantly insufficient liquidity may lead to a new equilibrium of supply and demand, seasonal changes in money supply pose a unique problem. Supply and demand during a season of sufficient liquidity create an equilibrium; during a season of insufficient liquidity, the equilibrium cannot be reached due to a lower money supply. However, demand and supply may be relatively stable. This leads to the imperfect allocation of goods and services introduced above, seasonally reducing an economy's welfare. Additionally, money cannot fully serve as a store of value in a situation of insufficient liquidity. The money supply is already insufficient to fully serve as a means of exchange. The two functions of money are mutually exclusive, so only money which is not used as a means of exchange can be saved. The scarce money supply thus leads to decreased savings. Hence, money cannot fully function as a store of value. In this way, seasonally insufficient money supply leads to a situation in which money can neither completely fulfill its functions as a means of exchange nor store of value.

Even though the effects of the seasonal variation in the money supply are substantial, literature on this topic are quite scattered. Seasonal variation in money supply is acknowledged in empirical studies; however, it is usually controlled for, instead of being studied in its own right (e.g., Roffia and Zaghini 2007). Seasonality is treated as an error in variables (Sims 1974, p. 618), ignoring that it may have significant effects on the economy. In one of the rare studies that focus on seasonal patterns, the authors find that seasonal fluctuations significantly impact consumption and investment (Barsky and Miron 1989, p. 504). However, little research exists on how this seasonal fluctuation in money supply affects local and national economies.

In a situation of seasonally insufficient liquidity, we thus identify three core economic disadvantages:

- Decreased sales: Imperfect allocation leads to excess supply, that is, less sales than in a situation of sufficient liquidity (means of exchange).

- Decreased consumption. Imperfect allocation leads to excess demand, that is, less consumption than in a situation of sufficient liquidity (means of exchange).

- Decreased savings. Consumers lack sufficient liquidity to meet their demands, so they also lack excess funds which could be saved (store of value).

Seasonal liquidity is present especially in rural areas with a majority of population employed in the agricultural sector. In these local economies, income is created once a year during harvest 
season (Hong and Hanson 2016, p. 5). It constantly decreases as goods and services, such as fertilizers, are consumed (Fink et al. 2018, p. 1). Such investments are not only local but also done in urban areas, and therefore continually decrease liquidity for the entire rural area. The poor especially are affected by seasonal income as they are forced to cut food intake with decreasing liquidity (Lipton 1986, p. 4). This seasonality is especially pronounced with volatile food prices, as consumption additionally decreases as food prices increase (Kaminski et al. 2014, p. 24).

Bank credits usually address these problems, offering extra funds to individuals and businesses when they lack sufficient liquidity to meet their demands. However, especially in rural areas in the Global South, many of the poor who are in need of credits do not have access to financial institutions (Demirguc-Kunt et al. 2018, p. 35). The offers of these institutions is not tailored to the poor rural population. In this situation, individuals with seasonally low liquidity cannot increase their funds. A solution specific to rural areas in the Global South is the microfinance concept. Using the peer pressure of dense rural networks, it does not require collateral but rather depends on mutual trust in a group of individuals which share a credit. The concept allows individuals to access credits who would not be considered credit-worthy in a different context. However, the interest rates are high in comparison to ordinary bank credits, diminishing liquidity in a long-term perspective. It may therefore constitute a poverty trap for borrowers (Ahlin and Jiang 2008, p. 14). Also, microfinance institutions draw on money supply that already exists in the region. In a season of insufficient liquidity, this means a re-distribution of already few resources, instead of additional money supply which is needed to address the issues enumerated above. Microcredits therefore appear to be a suboptimal or even a counter-productive solution for seasonally insufficient liquidity. In the following analysis, we therefore do not consider microcredit as an option to alleviate liquidity issues, but rather introduce an alternative.

\subsection{Community Currencies in a Situation of Seasonally Insufficient Liquidity}

In a situation with seasonally low liquidity alleviated by neither bank nor microfinance credits, a community currency may have a stabilizing effect on the money supply. In terms of the equation of exchange, it offers an additional source of money supply $M$, enlarging the money supply $M$ to

$$
M=M_{N}+M_{C}
$$

where $M_{N}$ is the supply of national currency and $M_{C}$ is the supply of community currency. While $\mathrm{M}_{\mathrm{N}}$ fluctuates throughout the year, $M_{C}$ stays constant, stabilizing the overall money supply for the community. This is true for community currencies both with and without collateral. For a community currency without collateral, the introduction of the community currency increases the total money supply $M$. A community currency which does draw on collateral (i.e., national currency has to be exchanged into community currency) does not change the initial total money supply $M$. However, we neglect this effect and assume that the amount of issued community currency is too low in comparison with the national money supply to cause inflation. This paper solely focuses on the effect of a community currency to stabilize the money supply, in the awareness that this is only one factor in explaining its economic impact.

As a means of exchange, the community currency is not as fungible as national currency (Stodder 2009, p. 84) since the transactions are limited to the community. Therefore, the national currency is generally preferable. However, in a situation of insufficient liquidity, a transaction with a community currency is preferable to no transaction. Thus, a dual-currency system appears, in which some transactions are fulfilled in community currency, and others in national currency. If some transactions which are prevented by insufficient liquidity of the national currency can be fulfilled with community currency, the welfare losses can be decreased (as symbolized by the yellow area in Figure 1). In this way, economic advantage is created. This can be measured directly in increased sales and consumption. 
The community currency also has an effect on money as a store of value. If only a single currency is used, this function competes directly with the function as a means of exchange. However, in a dual-currency system, different currencies can take different functions. As the community currency is less fungible, it is preferable to spend it as quickly as possible. Therefore, while a community currency can function as a store of value (Slay 2011, p. 3; Martignoni 2012, p. 5; Zagata 2004, p. 481), this function is outweighed by its function as a means of exchange (CCIA 2015, p. 100). Since the national currency is more fungible, it is more likely that members save it, using it as a store of value. This effect can be measured in increased savings of the national currency.

A community currency may thus stabilize a local economy in a situation of seasonally insufficient liquidity. In stabilizing the money supply, it may help to obtain the equilibrium between supply and demand, and thus increase both sales and consumption. It may increase savings, mainly in national currency. A community currency may therefore be a viable alternative to traditional ways of addressing seasonally insufficient liquidity and provide a tool to stabilize local economies. Hence, we assume community currencies are economically advantageous to the local community in a surrounding of insufficient liquidity.

\subsection{Hypothesis}

This line of thought leads us to the following set of hypotheses. Since it is difficult to directly prove a hypothesis, we wish to reject its opposite. We therefore formulate the hypothesis aligning with the theoretical framework provided above as the alternative hypothesis, $\mathrm{H}_{0}$ and $\mathrm{H}_{1}$.

\section{$\mathbf{H}_{\mathbf{0}}$ : Community currencies are only economically advantageous in an environment of sufficient liquidity.}

$\mathbf{H}_{1}$ : Community currencies are only economically advantageous in an environment of insufficient liquidity.

In the following section, we test the hypothesis presented above qualitatively by regarding two cases of different community currencies: the German Chiemgauer and the Kenyan Sarafu Credit. While the Chiemgauer operates in a surrounding of sufficient liquidity, the Sarafu Credit operates in a surrounding of seasonally insufficient liquidity. We use the three indicators discussed in Section 2.3 to measure the respective community currency's impact: sales, consumption and savings. If these indicators increase due to the community currency, we assume the community currency is economically advantageous. If none of these indicators improve due to the community currency, we assume it does not have a positive economic impact. If these cases lead to a rejection of the null hypothesis, we assume the alternative hypothesis to be true. Community currencies are then only able to unroll their full potential of additional money supply if they operate in a surrounding of insufficient liquidity.

\section{Testing the Hypothesis}

This section tests our hypothesis, first directly and then indirectly. The first case examines an environment of sufficient liquidity, the second a situation of seasonally insufficient liquidity. We then examine implications for our hypothesis and conclude with remarks on limitations and possibilities of further research.

\subsection{Chiemgauer: An Environment of Sufficient Liquidity}

The German Chiemgauer is known as a strong community currency in comparison with others in the Global North (Marshall and O'Neill 2018, p. 273). It even inspired other currencies such as the British BerkShares (Seyfang and Longhurst 2013, p. 74). If we can show that this strong currency acts in an environment of sufficient liquidity, yet does not entail economic advantages, the null hypothesis can be rejected.

The community currency was started in 2003 as a school project in the Chiemgau region (Thiel 2011, p. 240). Supported by surrounding businesses and banks (Dittmer 2013, p. 8), it has grown to a network of 419 participating businesses and many more members (Chiemgauer Regiogeld 
UG 2019). Members can either pay using bills or giro-money via cards provided by local banks (Thiel 2011, p. 240). To increase the speed of circulation, a demurrage of $2 \%$ every three months has been introduced (Dittmer 2013, p. 8); 3\% of sales are donated to local clubs (Thiel 2011, p. 244). The Chiemgauer is directly convertible to the national currency, the Euro (Thiel 2011, p. 323).

In comparison to other parts of Germany, the Chiemgau region is economically strong (Thiel 2011, p. 324). Also, it is touristy and home to many hotels (Roesl 2007, p. 5), attracting liquidity from other regions, both German and internationally. With a strong economic standing and external increase of liquidity, it can be assumed that lack of liquidity is generally not an issue. Since local banks participate in the network, we assume that members have access to bank credits if they are in need. Members are mostly aged 40 to 60, with an education and salary which are both above-average (Thiel 2011, p. 255). Since this group is employed and well-paid, it can be assumed that its members do not lack liquidity and have access to bank credits if they are in need. We therefore assume the Chiemgauer circulates in an environment of sufficient liquidity.

Despite its high level of circulation in comparison to other community currencies, the Chiemgauer only accounts for 0.01 percent of the regional economic product (Dittmer 2013,9). This indicator for currency acceptance within the regional network is rather low. However, we examine its economic impact and not its popularity, which can also be impacted by non-economic factors. Consequently, the low level of this indicator is an indication, but not evidence of a lack of economic advantages. Additionally, there are strong doubts whether the Chiemgauer motivates its members to switch currency without further economic consequences (Dittmer 2013, p. 8, p. 10). Members state they do not use the Chiemgauer as a complementary currency; rather, it is regarded as only one form which money may assume (Thiel 2011, p. 323). Therefore, it does not add liquidity or change the way in which members use their resources. In this way, the Chiemgauer does not increase savings. Members also state they have not changed their quantity of consumption, but rather switched to participating businesses (Thiel 2011, p. 302). Therefore, the Chiemgauer achieves a regional inter-business shift in sales instead of increasing them. If a single participating business experiences an increase in sales, other businesses lose clients and experience decreasing sales. Consequently, the Chiemgauer increases neither consumption nor sales for its members. Thus, the Chiemgauer fails to address the economic issues listed above. It does not increase savings, consumption or sales but rather represents a luxury money (Thiel 2011, p. 282) that is only used by a certain clientele, apparently for non-economic reasons.

\subsection{Sarafu Credit: An Environment of Insufficient Liquidity}

Kenyan Sarafu credit is a very well-researched community currency, especially in comparison to other currencies in the Global South (Cauvet 2018; Ruddick et al. 2015). If it can be shown that it carries economic advantages in an environment of insufficient liquidity, the null hypothesis can be rejected.

Started in 2011 in an informal settlement in Mombasa as the Bangla-Pesa, the community currency developed into the larger network of Sarafu credit. It slowly spread to different regions, both rural and urban, reaching 12 communities recently (Cauvet 2018, p. 6). Members can use bills in the first communities that joined, but recently a blockchain-based digital solution similar to mobile money has been introduced. It is intensely used, with 40,000 transactions made by 4065 members in just a year (Grassroots Economics 2019). While technically feasible, demurrage is currently not implemented. Sarafu credit is not convertible to the national currency; the total amount in circulation is increased with every new member endowed with an initial sum.

Sarafu credit members are generally poor and live in both rural areas (Cauvet 2018, p. 22) and urban informal settlements (Ruddick et al. 2015, p. 2). A pattern of seasonal liquidity can not only be shown for rural (Hong and Hanson 2016, p. 3), but also for urban areas: An informal settlement in Mombasa seasonally disposes of $144 \%$ more supply than is demanded during a season of insufficient liquidity (Ruddick et al. 2015, p. 18). However, liquidity cannot be restored in a sufficient way with formal bank credits. Sarafu credit members are usually poor and female, hence they are members of society with the least access to financial institutions (Demirguc-Kunt et al. 2018, p. 37). This impedes 
access to formal credits for a majority of its members. With seasonal changes in liquidity, but insufficient access to bank loans, we assume that liquidity in the environment of Sarafu credit is low.

Studies on the impact of Sarafu credit show that members benefit economically in various ways. Daily purchases in community currency allow members to save money in national currency which they would have spent otherwise (Ruddick 2011, p. 8). Savings can then be used to invest in members' businesses, advancing opportunities of local economic growth and higher levels of liquidity. Also, members significantly increase their consumption. Members have a significantly higher food consumption than non-members, as well as a generally higher food budget (Cauvet 2018, pp. 21-22). This may be a case of inverse correlation; that is, individuals with a higher food consumption and budget may be more likely to join the network than individuals with a lower consumption and budget. However, in the context of increased savings and a high proportion of food in reported transactions (Grassroots Economics 2019), a causal relationship between membership and increased consumption is likely. Moreover, sales within the network increase. In the case of Bangla-Pesa, the community currency accounted for $22 \%$ increase in monthly income (Ruddick et al. 2015, p. 6). With both consumption and sales increasing, we assume the community currency not only causes a shift of demand towards participating businesses, but an overall increase of sales.

Sarafu credit appears to be an efficient means to decrease the gap between excess supply and excess demand, increasing not only savings but also consumption and sales. This evidence might be questioned if only one of the issues introduced above were addressed. However, in interaction of all three issues, it seems that Sarafu credit is indeed economically advantageous.

\subsection{Implications for Hypothesis}

The case studies above address our null hypothesis from two different perspectives, helping to evaluate whether or not it can be rejected. In the case of the Chiemgauer, which circulates in an environment of sufficient liquidity, we show it is not economically advantageous. This result is incongruous with our null hypothesis which predicts economic advantages. The hypothesis can therefore be rejected; the community currency does not bring economic benefits in an environment of sufficient liquidity.

The case of Sarafu credit shows economic advantages in an environment of insufficient liquidity. This finding is incongruous with the null hypothesis predicting no economic advantages in this situation. The hypothesis can therefore be rejected; the community currency is connected with economic benefits in an environment of insufficient liquidity.

Combined, these two findings reject the null hypothesis and lead us to assume the alternative hypothesis: Community currencies are only economically advantageous in an environment of insufficient liquidity. While other factors may also be important, this finding points to a specific failure in the monetary system which community currencies can address. Seasonal changes in money supply which usually lead to changes in sales and consumption can be addressed. By providing a constant (less fungible) money supply, a community currency acts as an additional means of exchange and decreases the transactions which are prevented by the fluctuating national money supply. This leads to a more stable consumption of goods and services throughout the year and increases savings in national currency.

It seems that at least in this point, community currencies may only be economically advantageous if there is a failure in the monetary system. The German Chiemgauer operates in a monetarily stable environment with a sufficient money supply. The demand for additional liquidity is already answered through easily accessible loans. The community currency cannot function as a buffer in this environment. The Sarafu Credit on the other hand operates in an environment which fails its citizens; the extreme seasonal changes in money supply lead to changes in consumption and sales. The demand for additional liquidity is not satisfied by loans, so the community currency can fully take its function as a buffer and alleviate the impact of the monetary system's failure. 
In future considerations of implementing community currencies, this finding may be useful; also, it may provide an innovative way of addressing economic problems caused by insufficient levels of liquidity.

\subsection{Limitations and Further Research}

Due to the limited scope of this study, the analysis was confined in various ways. In the following, we explain these limitations and propose further directions of study. Addressing them may lead to a more holistic view of the subject.

The study is limited to two case studies. These may be special cases and therefore not representative for other community currencies. Considering the comprehensive nature of our hypothesis, expanding the analysis to other networks can prove insightful. The hypothesis may be tested more thoroughly to evaluate if our results hold up in other communities. Additionally, the study only examines, in a qualitative way, evidence on economic impacts found by other researchers. While this is a valid introductory method, it complicates direct comparison between the two cases. A quantitative approach may improve results, providing data which is directly comparable between networks. This also applies to the examination of the level of liquidity in their respective environment. Within the scope of this paper, only a superficial study of liquidity was possible, based on available data on the respective networks' region and members. To increase precision and enable direct comparability, metrics to measure liquidity could be developed and collected in the communities of interest. Generally, the study is preliminary. Its results may further be tested in a combination of the approaches addressed above. The number of examined community currencies could be increased while quantitative methods could facilitate comparison. Collecting such panel data is intensive in time and resources but would provide a more complete picture of reality.

\section{Conclusions}

This study set out to examine how community currencies can be economically advantageous in a surrounding of seasonally insufficient money supply. This phenomenon has, so far, been neglected as a potential cause of a community currency's economic success. Preventing transactions, it causes a lean season during which consumption, sales and savings decrease. A community currency may counteract this effect in stabilizing the money supply throughout the year, and especially increasing the money supply during the lean season. In this way, a community currency may decrease the number of transactions which are prevented by insufficient liquidity. This increases consumption, sales and savings, and generally increases welfare.

Building on existing literature on both community currencies and money supply, we developed a hypothesis stating community currencies are only economically advantageous in an environment of insufficient liquidity. Since it is difficult to prove this hypothesis, we aimed to reject the opposite, which we refer to as our null hypothesis. We tested this hypothesis with two case studies. The first case showed no economic benefits in an environment of sufficient liquidity. The second case showed economic benefits in an environment of insufficient liquidity. These results were incongruous with our null hypothesis, which was consequently rejected. Instead, we accepted the alternative hypothesis, stating that community currencies are only economically advantageous in an environment of insufficient liquidity since they stabilize the effects of seasonal liquidity.

The limits of this study point towards possible areas of future research. The number of studied communities could be increased to further validate the hypothesis. Additionally, a quantitative approach of examining a community currency's level of liquidity and economic success would enable direct comparison and provide further insights. A panel study would combine these two methods.

This study not only fills a research gap left by current literature, but also provides an analysis of an important success factor of community currencies in pursuing economic objectives. It may improve future implementations which aim to address economic challenges. The implementation of a community currency may need extensive planning and coordination with the central bank and is more 
of a grass-roots effort. However, in a surrounding of seasonally insufficient money supply which is not alleviated by bank credits, community currencies may be an effective policy tool to increase economic welfare. Our findings may also enable innovative ways to alleviate poverty, especially in areas who need them the most.

Funding: The open access publication was funded by SLUB Dresden.

Acknowledgments: This paper is based on a thesis for a course at Technische Universität Dresden.

Conflicts of Interest: The funders had no role in the design of the study; in the collection, analyses, or interpretation of data; in the writing of the manuscript, or in the decision to publish the results.

\section{References}

Ahlin, Christian, and Neville Jiang. 2008. Can Micro-Credit Bring Development? Journal of Development Economics 86: 1-21. [CrossRef]

Barsky, Robert, and Jeffrey Miron. 1989. The Seasonal Cycle and the Business Cycle. Journal of Political Economy 97: 503-34. [CrossRef]

Bonanno, Andrew. 2018. Assessing Local Mutual Credit as a Socioeconomic Tool for Farmers in New York State's Hudson Valley. International Journal of Community Currency Research 22: 89-102.

Cauvet, Marion. 2018. Voucher Systems for Food Security. A Case Study on Kenya's Sarafu-Credit. Working Paper. Available online: https://www.researchgate.net/publication/323550475_Voucher_Systems_for_Food_ Security_A_Case_Study_on_Kenya\%27s_Sarafu-Credit_Working_paper (accessed on 1 September 2020).

CCIA. 2015. People Powered Money. Designing, Developing \& Delivering Community Currencies. London: New Economics Foundation, Available online: https://monneta.org/wp-content/uploads/2017/01/CCIA-bookPeople-Powered-Money.pdf (accessed on 1 September 2020).

Chiemgauer Regiogeld UG. 2019. Anbieterverzeichnis. Available online: https:/www.chiemgauer.info/verzeichnis/ anbieterverzeichnis/ (accessed on 30 September 2019).

Collins, Josh Ryan, Ludwig Schuster, and Tony Greenham. 2012. Energising Money. An Introduction to Energy Currencies and Accounting. London: New Economics Foundation.

De Janvry, Alain, Elisabeth Sadoulet, and Rinku Murgai. 2002. Rural Development and Rural Policy. Handbook of Agricultural Economics 2: 1593-658.

Demirguc-Kunt, Asli, Leora Klapper, Dorothe Singer, Saniya Ansar, and Jake Hess. 2018. The Global Findex Database 2017: Measuring Financial Inclusion and the Fintech Revolution. The World Bank. Available online: https://openknowledge.worldbank.org/handle/10986/29510 (accessed on 1 September 2020).

Dittmer, Kristofer. 2013. Local Currencies for Purposive Degrowth? A Quality Check of Some Proposals for Changing Money-as-Usual. Journal of Cleaner Production 54: 3-13. [CrossRef]

Fink, Günther, Kelsey Jack, and Felix Masiye. 2018. Seasonal Liquidity, Rural Labor Markets and Agricultural Production. No. w24564. Cambridge: National Bureau of Economic Research.

Fisher, Irving. 1912. The Purchasing Power of Money: Its' Determination And Relation to Credit Interest and Crises. New York: Macmillan. [CrossRef]

Godschalk, Hugo. 2011. Why Demurrage? Paper presented at International Conference on Community and Complementary Currencies, Lyon, France, February 16-17.

Gomez, Georgina, and Bert Helmsing. 2008. Selective Spatial Closure and Local Economic Development: What Do We Learn from the Argentine Local Currency Systems? World Development 36: 2489-511. [CrossRef]

Grassroots Economics. 2019. Looking Back at 40,000 Blockchain Transactions. Available online: https:// www.grassrootseconomics.org/post/looking-back-at-40000-blockchain-transactions?page=2 (accessed on 1 September 2020).

Hong, David, and Stephanie Hanson. 2016. Scaling up Agricultural Credit in Africa. In Frontier Issues Brief. Presented by the One Acre Fund to the Ending Rural Hunger Project at Brookings Institution. Washington, DC: Brookings Institution.

Kaminski, Jonathan, Luc Christiaensen, and Christopher L. Gilbert. 2014. The End of Seasonality? New Insights from Sub-Saharan Africa. In World Bank Policy Research Working Paper. Washington, DC: The World Bank, p. 6907. Available online: http://econ.worldbank.org (accessed on 1 September 2020). 
Krohn, Gregory, and Alan Snyder. 2008. An Economic Analysis of Contemporary Local Currencies in the United States. International Journal of Community Currency Research 12: 55-68.

De la Rosa, Josep Lluis, and James Stodder. 2015. On Velocity in Several Complementary Currencies. International Journal of Community Currency Research 19: 114-27.

Lipton, Michael. 1986. Seasonality and Ultrapoverty. IDS Bulletin 17: 4-8. [CrossRef]

Lukschandl, Eduard. 2020. Aus Der Geschichte Lernen: Das Wunder von Wörgl. In Zirkulares Grundeinkommen und Nullzinspolitik. Wiesbaden: Springer Gabler, pp. 19-20. [CrossRef]

Marshall, Adam, and Daniel O'Neill. 2018. The Bristol Pound: A Tool for Localisation? Ecological Economics 146: 273-81. [CrossRef]

Martignoni, Jens. 2012. A New Approach to a Typology of Complementary Currencies. International Journal of Community Currency Research 16: 1-17.

Michel, Arnaud, and Marek Hudon. 2015. Community Currencies and Sustainable Development: A Systematic Review. Ecological Economics 116: 160-71. [CrossRef]

Roesl, Gerhard. 2007. Regionalgeld in Deutschland: Eine Große Idee in Kleinräumiger Wirkung. Orientierungen Zur Wirtschafts-Und Gesellschaftspolitik 111: 41-45.

Roffia, Barbara, and Andrea Zaghini. 2007. Excess Money Growth and Inflation Dynamics. International Finance 10: 241-80. [CrossRef]

Ruddick, William. 2011. Eco-Pesa: An Evaluation of a Complementary Currency Programme in Kenya's Informal Settlements. International Journal of Community Currency Research 15: 1-12.

Ruddick, William, Morgan Richards, and Jem Bendell. 2015. Complementary Currencies for Sustainable Development in Kenya: The Case of the Bangla-Pesa. Journal of Community Currency Research 19: 18-30.

Schraven, Jorim. 2001. The Economics of Community Currencies. A Theoretical Perspective. Available online: http://www.jorim.nl/economicscommunitycurrencies.pdf (accessed on 1 September 2020).

Seyfang, Gill, and Noel Longhurst. 2012. Money, Money, Money? A Scoping Study of Grassroots Complementary Currencies for Sustainability. 3S Working Paper 2012-02. Available online: www.3S.uea.ac.uk (accessed on 1 September 2020).

Seyfang, Gill, and Noel Longhurst. 2013. Growing Green Money? Mapping Community Currencies for Sustainable Development. Ecological Economics 86: 65-77. [CrossRef]

Sims, Christopher. 1974. Seasonality in Regression. Journal of the American Statistical Association 69: 618-26. [CrossRef]

Slay, Julia. 2011. More than Money. London: NESTA.

Stodder, James. 2009. Complementary Credit Networks and Macroeconomic Stability: Switzerland' s Wirtschaftsring. Journal of Economic Behavior E Organization 72: 79-95. [CrossRef]

Stodder, James, and Bernard Lietaer. 2016. The Macro-Stability of Swiss WIR-Bank Credits: Balance, Velocity, and Leverage. Comparative Economic Studies 58: 570-605. [CrossRef]

Thiel, Christian. 2011. Das Bessere Geld. Wiesbaden: VS Verlag für Sozialwissenschaften.

Zagata, Lukáš. 2004. Complementary Currency Systems as a Source of Endogenous Development. ZEMEDELSKA EKONOMIKA-PRAHA 50: 477-84.

Publisher's Note: MDPI stays neutral with regard to jurisdictional claims in published maps and institutional affiliations.

(C) 2020 by the author. Licensee MDPI, Basel, Switzerland. This article is an open access article distributed under the terms and conditions of the Creative Commons Attribution (CC BY) license (http://creativecommons.org/licenses/by/4.0/). 